\title{
Effect of Islamic marketing mix integration on the decision to stay at Sharia hotels in Indonesia
}

\section{Sri Devi, Anna Sardiana}

Islamic Finance and Islamic Banking Dept, Indonesia Banking School anna.sardiana@ibs.ac.id 


\title{
Effect of Islamic marketing mix integration on the decision to stay at Sharia hotels in Indonesia
}

\author{
Sri Devi, Anna Sardiana \\ Islamic Finance and Islamic Banking Dept, Indonesia Banking School \\ anna.sardiana@ibs.ac.id
}

Received: 24/6/2021 Revised: 6/7/2021 Accepted: 12/7/2021 DOI: https://doi.org/10.31559/IJHTS2020.2.1.9

\begin{abstract}
By establishing Indonesia as a halal tourist destination in 2019. This has an impact on increasing tourists for vacation. In visiting a place, lodging accommodations such as hotels are taken into consideration. With so many hotels that have a sharia concept, there will be competing for customers. A contemporary marketing mix is a tool that marketers can use to shape a characteristic of the services offered. However, there is an integrated Islamic marketing mix which is a marketing concept by combining contemporary and Islamic marketing concepts. Therefore, this study aims to examine the effect of the integration of the Islamic marketing mix (Pragmatism and Product, Pertinence and Promotion, Palliation and Price, Peer-Support and People, Pedagogy and Physical Environment. The data collection technique used a questionnaire distributed online with a sample of 175 respondents who had stayed at Islamic hotels / inns in Indonesia. In analysing data using SPSS 21. The results of this study are Pragmatism and Product, Pertinence and Promotion, Palliation and Price and Peer-Support and People have no influence. Meanwhile, Pedagogy and Physical Environment, Persistence and Process as well as Patience and Place influence the decision to stay.
\end{abstract}

Keywords: Decision to Stay; Islamic Marketing Mix; Sharia Hotels; Halal Tourism.

\section{Introduction}

Halal tourism is a journey to enjoy all-natural wealth and / or tourist attractions in a country with halal essence in it, but the activities are not only for Muslims but for all groups (Husen and Zhafira, 2019). Islam views tourism as something that needs to be implemented to take lessons from these activities, this is stated in QS Al-Mulk verse 15:

"It is He who made the earth tame for you - so walk among its slopes and eat of His provision - and to Him is the resurrection"

To encourage foreign exchange, the tourism sector can use (Kompas, 2019). With a Muslim population in Indonesia of 207,176,162 this will be an opportunity to develop halal tourism (Kavanillah and Ridlwan, 2018). With the development of halal tourism which is quite good, there must be adequate accommodation for Muslim and nonMuslim tourists, such as lodging places (Satriana \& Faridah, 2018). Islamic hotels make a significant contribution to tourism in Indonesia (Abdul, 2016). Islamic hotels make a significant contribution to tourism in Indonesia (Abdul, 2016). With more and more hospitality businesses, the more and more intense competition in the service sector will also increase the choice of visitors to choose hotels (Mansyuroh, 2018).

The marketing mix is used to run a business because the marketing mix is a tool to shape the characteristics of the services offered. The marketing mix consists of 4Ps (Product, Price, Place, Promotion) then added with 3P of services, namely People, Physical Evidence and Process (Kotler \& Armstrong, 1997). Wilson (2012) presents the results of his research on the Islamic Marketing Mix, and he argues that the marketing mix for Islam will be different from the usual marketing mix. Then the research was continued by Hashim and Hamzah (2014), in which the results of their research resulted in a new concept regarding the Islamic Marketing Mix, in which the Islamic and contemporary perspectives should not be separated. This concept can be significant if it can be combined with modern marketing concepts. They also realize Islamic teachings into a marketing mix called 7P which consists of Pragmatism and Product, Pertinence and Promotion, Palliation and Price, Peer-Support and People, Pedagogy and Physical Environment, Persistence and Process \& Patience and Place. 
With a marketing mix, a business will get maximum results, especially for companies that run service businesses such as the hotel industry. Therefore, using the marketing mix is the most important thing. Then with a new concept regarding the integration of conventional and Islamic marketing. So how is the influence of each variable proposed by Hashim and Hamzah (2014) with a person's decision to stay at a sharia hotel. The things that are reported will be examined in this study.

\section{Literature Review}

Consumer behavior is a decision making in determining, buying, using and utilizing services, products and ideas to satisfy desires and needs (Firmansyah, 2018). In marketing itself, it cannot be separated from consumer behavior, if the needs of a consumer are not met, the consumer will show disappointed behavior (Hermawan, 2015). According to Kotler (2009) there are 2 factors that influence consumer behavior, first, controllable factors such as the marketing mix and second, factors that cannot be controlled but must be considered, such as cultural, social, personal, and psychological factors (Hermawan, 2015).

A purchase decision will only occur if there are several alternative options (Schiffman and Kanuk, 2008). Kotler (2009) explains that in general consumers will experience the process of stages before deciding, which includes problem recognition, information search, alternative evaluation, purchase decisions and post-purchase behavior (Tehuayo, 2018). Engel et. al. (1994) stated that the process of a decision is influenced by several things such as individual differences, environment, marketing strategies and psychological processes. The purchase decision is made to be able to choose halal products, this is stated in QS Al-Baqarah paragraph 168:

"O mankind, eat from whatever is on earth (that is) lawful and good and do not follow the footsteps of Satan. indeed, he is to you a clear enemy."

Marketing management has the goal of making consumer opinions about a product such as in terms of trust and maintaining relationships between consumers and producers (Widyawati, 2015). This can be learned by planning, analysing and identifying what consumers want so that individual and organizational goals can be achieved. The marketing mix is a marketing tool in a company, which, if used, will produce any response the target market wants. In 2012 the Islamic Marketing Mix concept was developed by Wilson. He introduced the 7P for the Islamic Marketing Mix. Then followed by Hashim and Hamzah (2014).

The meaning of Pragmatism and Products in Hashim and Hamzah (2014) also explained that the Prophet Muhammad SAW when trading he chose to sell goods that are not rotten and do not mix their products. Then the seller must sell the goods or services that the customer needs, and the seller must separate the products depending on their quality so that the customer can clearly select the product. In the Al-Quran Surah An-Nisa verse 29 which means:

" O you who have believed, do not consume one another's wealth unjustly but only (in lawful) business by mutual consent. And do not kill yourselves (or one another). Indeed, Allah is to you ever Merciful."

Pertinence and Promotion in Hashim and Hamzah's research (2014) it is also explained that a product must be communicated with ethical boundaries, because Islam prohibits the practice of "over promising". Which means that the seller must inform the customer about the condition of their product, so that the customer does not feel cheated. In Surah An-Nur verse 11 which means:

"Indeed, those who came with falsehood are a group among you. Do not think it bad for you; rather it is good for you. For every person among them is what (punishment) he has earned from the sin, and he who upon himself the greater portion thereof - for him is a great punishment."

Palliation and Price in Hashim and Hamzah (2014) explain that palliation describes the minimization of difficulties faced by marketers and customers alike. In addition, price is not only about income and benefits, but also recognizes costs borne by customers. Examples are giving discounts to customers or the existence of financing cuts to ease their burden on making purchases when the economy affects such as inflation.

Peer-Support and People in Hashim and Hamzah (2014) it is explained that the Prophet Muhammad SAW never disputed and deceived stakeholders and in carrying out transactions the seller must be kind to customers or buyers. With such an attitude, a salesperson will get blessings in sales and will increase enthusiasts more (Sumantri and Yuliza, 2015).

Pedagogy and Physical Environment in Hashim and Hamzah (2014) explain that sellers must have good integrity in serving customers. That way you can build a good relationship between sellers and buyers. The importance of business ethics can be likened to the foundation of a building. This plays a very important role as a pillar and a foundation in building a building framework (Mardoni, 2017). If there is not all of that then you cannot build a building, it is the same as no business without ethics, honesty, and integrity in it.

Persistence and Process can be interpreted that customer may have a first impression in terms of processes such as delivery and persistence described by marketers (Hashim and Hamzah, 2014). In Islam, the buying and selling process must reach a mutual agreement. In Surat An-Nisa verse 29 describes the practice of buying and selling regarding agreements or negotiations, namely: 
" O you who have believed, do not consume one another's wealth unjustly but only (in lawful) business by mutual consent ..."

The last is Patienceand Place in Hashim and Hamzah (2014) explain that the distribution process in an Islamic economy must be in accordance with the principles of sharia. In distributing the product, it must be evenly distributed so that all consumers can enjoy the product (Syukur, 2018). In distribution, it is also not allowed to commit wrongdoing to other competitors.

A sharia hotel can be defined as a hotel which in the procurement, provision and use of products and facilities as well as in their operations do not violate sharia rules (Sofyan, 2011). Where sharia hotels have their own criteria ranging from facilities that can separate men and women, checking guests at check-in, marketing it must be open to anyone, food and drinks provided must be halal food and drinks and in decorating it must be adjusted to value beauty in Islam.

In this study it is based on previous research on which the research is based, here is a table of previous studies:

Table (1): Previous Research

\begin{tabular}{|c|c|c|c|c|}
\hline No. & Researcher Name / Research Title & Variable & Analysis Tools & Result \\
\hline 1. & $\begin{array}{l}\text { Christiyanto and Astutik (2018) "Integrated } \\
\text { Marketing and Customers Decision Saving } \\
\text { Funds in Islamic Banks" }\end{array}$ & 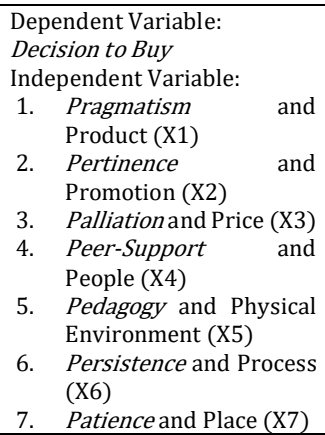 & $\begin{array}{l}\text { SEM-PLS method } \\
\text { using the WarpPLS } \\
5.0 \text { analysis tool }\end{array}$ & $\begin{array}{l}\text { The results of this study conclude that } \\
\text { Pragmatism, Persistence and } \\
\text { Pertinence affect customer decisions to } \\
\text { save at Islamic Banks, while Palliation, } \\
\text { Patience, Peer-Support, and } \\
\text { Pedagogy does not affect the } \\
\text { customer's decision to save in Islamic } \\
\text { Bank. }\end{array}$ \\
\hline 2. & $\begin{array}{l}\text { Gatot Wijayanto (2015) "The Effect of Service } \\
\text { Marketing Mix in Choosing the Decision to } \\
\text { Consumer Services Hotel: Studies in Hotel } \\
\text { Grand Zuri Pekanbaru" }\end{array}$ & 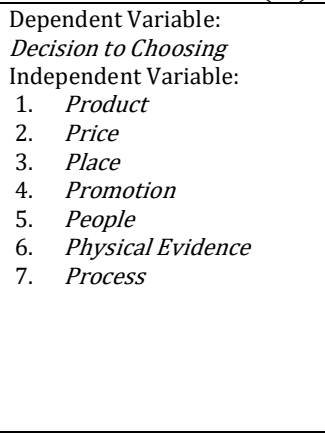 & SPSS & $\begin{array}{l}\text { The study concluded that based on the } \\
\text { results of the analysis of statistical test } \\
\text { calculations showed the simultaneous } \\
\text { marketing mix factor (overall test) had } \\
\text { a significant influence on consumer } \\
\text { decisions in choosing the Grand Zuri } \\
\text { Pekanbaru hotel. The marketing mix of } \\
\text { Grand Zuri Hotel services partly } \\
\text { through product, place, promotion, } \\
\text { process variables has no significant } \\
\text { effect, while price, person and physical } \\
\text { evidence variables have a significant } \\
\text { influence on consumer decisions in } \\
\text { using Grand Zuri Hotel Pekanbaru } \\
\text { services. }\end{array}$ \\
\hline 3. & $\begin{array}{l}\text { Sadaf Alam, Rafia Alam, Dr Riaz Ahmed \& } \\
\text { Waseem Ahmed (2017) "Discriminant } \\
\text { Analysis of Marketing Mix Factors' in } \\
\text { influencing th Use of Hotel Services in } \\
\text { Pakistan" }\end{array}$ & $\begin{array}{l}\text { Dependent Variable: } \\
\text { Choice of Accommodation } \\
\text { Independent Variable: } \\
\text { 1. } \quad \text { Product } \\
\text { 2. Price } \\
\text { 3. Place } \\
\text { 4. Promotion } \\
\text { 5. People } \\
\text { 6. Physical Evidence } \\
\text { 7. Process }\end{array}$ & SPSS & $\begin{array}{l}\text { This study encourages tourism and } \\
\text { hospitality industry players to have an } \\
\text { understanding of Pakistani domestic } \\
\text { and international tourists so that they } \\
\text { can focus their marketing strategies. } \\
\text { Tourist attractions must be in an easily } \\
\text { accessible location so as to attract } \\
\text { visitors. In the case of price fixing, it } \\
\text { must be in line with the domestic } \\
\text { market's ability to pay for the product. } \\
\text { Marketers should manage their } \\
\text { product portfolios so they can find new } \\
\text { ways to satisfy their visitors and } \\
\text { differentiate their offerings from } \\
\text { competitors. Due to the invisible nature } \\
\text { of services, marketers need to find } \\
\text { ways to take advantage of the service } \\
\text { experience. The tourism ministry } \\
\text { should have market partnerships and } \\
\text { associations with organizations that } \\
\text { offer tour, travel and hospitality } \\
\text { services. }\end{array}$ \\
\hline 4. & $\begin{array}{l}\text { Nurdin Sobari, Hardius Usman and M. Zainul } \\
\text { Wathani (2017) "The Influence of Sharia } \\
\text { Compliance and Marketing Mix on } \\
\text { Satisfaction and Intention of Muslim Tourist } \\
\text { to Revisit Sharia Hotel" }\end{array}$ & $\begin{array}{l}\text { Dependent Variable: } \\
\text { Muslim tourist satisfaction } \\
\text { Independent Variable: } \\
\text { 1. Product } \\
\text { 2. Price } \\
\text { 3. Promotion } \\
\text { 4. Place } \\
\text { 5. People } \\
\text { 6. Process } \\
\text { 7. Physical Evidence }\end{array}$ & SPSS & $\begin{array}{l}\text { This study shows that sharia } \\
\text { compliance, products, prices, processes } \\
\text { and physical evidence have a positive } \\
\text { and significant impact on the } \\
\text { satisfaction of Muslim tourists staying } \\
\text { at Islamic hotels. }\end{array}$ \\
\hline
\end{tabular}




\begin{tabular}{|c|c|c|c|c|}
\hline 5. & $\begin{array}{l}\text { Widyarini and Fitri Kartini (2014) "Variables } \\
\text { Affecting the Decision to Choose Sharia } \\
\text { Hotels" }\end{array}$ & 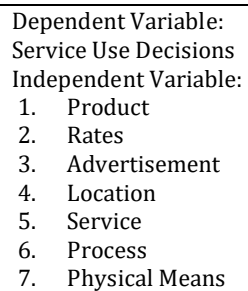 & SPSS & $\begin{array}{l}\text { Variable test results, hotel guests' } \\
\text { perceptions of products, rates and } \\
\text { processes have no effect on hotel guest } \\
\text { decisions to stay. Meanwhile, } \\
\text { advertisements, location, services and } \\
\text { physical facilities influence the } \\
\text { decisions of hotel guests to stay. }\end{array}$ \\
\hline
\end{tabular}

Research from Chirstiyanto and Astutik (2018) shows that Pragmatism and Product, Persistence and Process \& Pertinence and Promotion have an influence on the decision to save in Islamic banks. Meanwhile, Patience and Place, Pedagogy and Physical Environment, Peer-Support and People \& Palliation and Price have no influence on the decision to save in an Islamic bank.

Based on the explanations and theories that have been described, in this study, the measured aspects of the decision to stay (guests) at a sharia hotel / lodging (CD) include Islamic Marketing Mix Integration, namely: Pragmatism and Product (X1), Pertinence and Promotion (X2), Palliation and Price (X3), Peer-Support and People (X4), Pedagogy and Physical Environment (X5), Persistence and Process (X6) \& Patience and Place (X7). Then Here is a framework for developing a hypothesis:

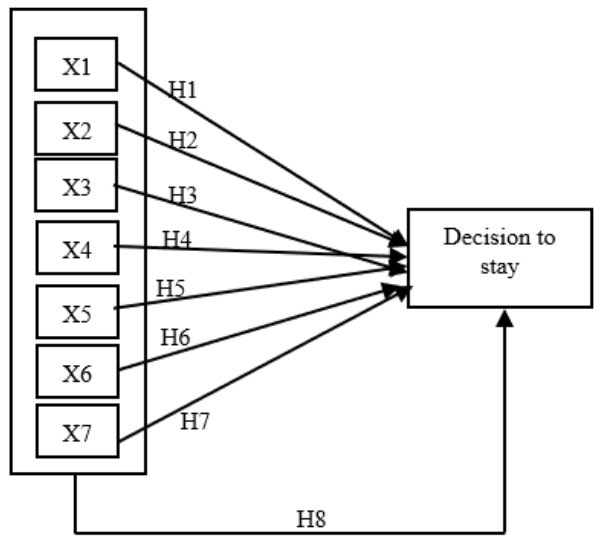

Figure (1): Research Model

Based on the explanation above, previous research and research framework, the first hypothesis can be proposed, Pragmatism and Product (PP1) influence the decision to stay at sharia hotel / inns; Pertinence and Promotion (PP2) influence decisions to stay at sharia hotels / inns; Palliation and Price (PP3) do not influence decisions to stay at sharia hotels / inns; Peer-Support and People (PP4) have no influence on decisions to stay at sharia hotels / inns; Pedagogy and Physical Environment (PP5) do not influence decisions to stay at sharia hotels / inns; Persistence and Process (PP6) influence the decision to stay at sharia hotels / inns; Patience and Place (PP7) do not influence the decision to stay at sharia hotel / lodging.

\section{Methods}

The objects used in this study are hotel guests who have stayed at sharia hotels / inns in Indonesia, whether it's star-rated hotels or not. In this study, the method used is a survey method with the type of questionnaire which is conducted online. The level of significance used in this study is 5\%. Determination of the number of samples in this study using Roscoe's theory, namely the number of sample members is at least 10 times the number of variables studied. So that the number of samples used is at least 80 respondents. However, the respondents collected in this study were 175 respondents. In this research, descriptive analysis and hypothesis testing were carried out. Data analysis using SPSS 21. The indicators used in this study are as follows:

Table (2): Operational Variables

\begin{tabular}{|c|c|c|c|}
\hline Variable & Definition & Indicator & Instrument \\
\hline $\begin{array}{l}\text { Pragmatism and } \\
\text { Product (PP1) }\end{array}$ & $\begin{array}{l}\text { Assessing truth and } \\
\text { meaning based on } \\
\text { scientific and real-world } \\
\text { approaches (Wilson } \\
2012 \text { in Hashim and } \\
\text { Hamzah, 2014) }\end{array}$ & $\begin{array}{l}\text { 1. These sharia hotels / inns only provide halal food and drinks } \\
\text { 2. Services at these sharia hotels / inns meet sharia service } \\
\text { standards (such as the direction of the Qibla for each room, there } \\
\text { is a prayer room, employees dress modestly) } \\
\text { 3. During my stay at this sharia hotel / inn, I got peace of mind } \\
\text { 4. During my stay at the hotel / inn, I did not see or listen to } \\
\text { someone who had committed an act that was not against Islamic } \\
\text { law } \\
\text { (Widyarini \& Kartini, } 2014 \text { and Christiyanto \& Astutik, 2018) }\end{array}$ & $\begin{array}{c}\text { Likert Scale } \\
(1-5)\end{array}$ \\
\hline $\begin{array}{l}\text { Pertinenceand } \\
\text { Promotion (PP2) }\end{array}$ & $\begin{array}{l}\text { Shows the relevance and } \\
\text { application of sharia so }\end{array}$ & $\begin{array}{l}\text { 1. Information about the facilities obtained is clear (such as price } \\
\text { and what is obtained). }\end{array}$ & $\begin{array}{l}\text { Likert Scale } \\
\quad(1-5)\end{array}$ \\
\hline
\end{tabular}




\begin{tabular}{|c|c|c|c|}
\hline & $\begin{array}{l}\text { that customers do not } \\
\text { feel cheated (Wilson } \\
2012 \text { in Hashim \& } \\
\text { Hamzah, 2014) }\end{array}$ & $\begin{array}{l}\text { 2. How to promote attractive and transparent (be it on the official } \\
\text { website, Instagram or hotel booking applications) } \\
\text { 3. Information about the hotel / inn is easy to find } \\
\text { 4. The information displayed in the hotel booking application is } \\
\text { clear } \\
\text { (Widyarini \& Kartini, } 2014 \text { and Christiyanto \& Astutik, 2018) }\end{array}$ & \\
\hline $\begin{array}{l}\text { Palliation and Price } \\
\text { (PP3) }\end{array}$ & $\begin{array}{l}\text { Selling goods or services } \\
\text { at a price in accordance } \\
\text { with the existing } \\
\text { circumstances. } \\
\text { (Hashim \& Hamzah, } \\
\text { 2014) }\end{array}$ & $\begin{array}{l}\text { 1. The price given is in accordance with the room facilities } \\
\text { 2. The price given is proportional to the service } \\
\text { 3. The price range offered is appropriate } \\
\text { 4. There are attractive promos displayed on Instagram / application } \\
\text { and hotel booking sites } \\
\text { (Kara, Parmitasari, Alwi and Risna, } 2019 \text { and Christiyanto \& Astutik, } \\
\text { 2018) }\end{array}$ & $\begin{array}{c}\text { Likert Scale } \\
(1-5)\end{array}$ \\
\hline $\begin{array}{l}\text { Peer-Support and } \\
\text { People (PP4) }\end{array}$ & $\begin{array}{l}\text { Serve customers well, } \\
\text { there are no lies or } \\
\text { conflicts with customers. } \\
\text { (Hashim \& Hamzah, } \\
\text { 2014) }\end{array}$ & $\begin{array}{l}\text { 1. When checking in and checking out the receptionist is always } \\
\text { friendly. } \\
\text { 2. Security is friendly while in the hotel / inn } \\
\text { 3. Office Boy does not interfere with comfort while at the hotel / inn } \\
\text { 4. The receptionist is responsive to my complaints } \\
\text { (Widyarini \& Kartini, 2014 and Christiyanto \& Astutik, 2018) }\end{array}$ & $\begin{array}{c}\text { Likert Scale } \\
(1-5)\end{array}$ \\
\hline $\begin{array}{l}\text { Pedagogy and } \\
\text { Physical } \\
\text { Environment (PP5) }\end{array}$ & $\begin{array}{l}\text { Integrity or things that } \\
\text { can be shown that are } \\
\text { good in serving } \\
\text { customers. In order to } \\
\text { establish good relations } \\
\text { between the two parties. } \\
\text { (Hashim \& Hamzah, } \\
\text { 2014) }\end{array}$ & $\begin{array}{l}\text { 1. The hotel / inn has a large building } \\
\text { 2. The hotel / inn has supporting facilities for worship (prayer room } \\
\text { or mosque) } \\
\text { 3. The hotel rooms are clean } \\
\text { 4. The hotel / inn provides prayer equipment in each room. } \\
\text { (Widyarini \& Kartini, } 2014 \text { and Christiyanto \& Astutik, 2018) }\end{array}$ & $\begin{array}{c}\text { Likert Scale } \\
(1-5)\end{array}$ \\
\hline $\begin{array}{l}\text { Persistence and } \\
\text { Process (PP6) }\end{array}$ & $\begin{array}{l}\text { A clear agreement } \\
\text { regarding the } \\
\text { transactions carried out } \\
\text { by the seller and the } \\
\text { buyer in order to avoid } \\
\text { misunderstanding. } \\
\text { (Hashim \& Hamzah, } \\
\text { 2014) }\end{array}$ & $\begin{array}{l}\text { 1. In the hotel booking process, the facilities that will be obtained } \\
\text { have been explained } \\
\text { The processing of food and beverage ingredients is guaranteed to } \\
\text { be halal } \\
\text { The booking procedure either through the website or hotel } \\
\text { booking application is guaranteed to be the same. } \\
\text { 4. In marketing the product, the hotel / inn explains the halal } \\
\text { aspects of the hotel } \\
\text { (Christiyanto \& Astutik, 2018) }\end{array}$ & $\begin{array}{c}\text { Likert Scale } \\
(1-5)\end{array}$ \\
\hline $\begin{array}{l}\text { Patience and Place } \\
\text { (PP7) }\end{array}$ & $\begin{array}{l}\text { Distribute their products } \\
\text { and services properly } \\
\text { and pay attention to } \\
\text { access coverage. } \\
\text { (Hashim \& Hamzah, } \\
\text { 2014) }\end{array}$ & $\begin{array}{l}\text { 1. The hotel / inn has a strategic location (close to the city center) } \\
\text { 2. The location of the hotel / inn is close to public transportation } \\
\text { 3. The environment around the hotel / inn is Muslim friendly } \\
\text { 4. The location of the hotel / inn is close to the location to be } \\
\text { addressed. } \\
\text { (Widyarini \& Kartini, } 2014 \text { and Christiyanto \& Astutik, 2018) }\end{array}$ & $\begin{array}{c}\text { Likert Scale } \\
(1-5)\end{array}$ \\
\hline Stay Decision (Y) & $\begin{array}{l}\text { Actions directly involved } \\
\text { in obtaining, consuming } \\
\text { and spend on products } \\
\text { and services, and there } \\
\text { are decision processes } \\
\text { that precede and follow } \\
\text { these actions. (Umar, } \\
2000 \text { in Supriyanto \& } \\
\text { Taali, 2018) }\end{array}$ & $\begin{array}{l}\text { 1. The hotel / lodging provides necessities with halal hotel } \\
\text { standards (prayer tools, Qibla direction, prayer room / mosque) } \\
\text { 2. Information about hotel / lodging products is easy to get (see } \\
\text { reviews from social media / hotel booking applications or } \\
\text { opinions from relatives) } \\
\text { 3. When I want to stay at a hotel / inn with a halal concept, I will } \\
\text { choose the hotel / inn that I choose as my first choice. } \\
\text { 4. My decision to choose the hotel / inn was right, because the } \\
\text { expectations and reality match the information I got } \\
\text { 5. I was satisfied with the hotel / lodging I chose and would } \\
\text { recommend to others } \\
\text { (Supriyanto \& Taali, 2018) }\end{array}$ & $\begin{array}{c}\text { Likert Scale } \\
(1-5)\end{array}$ \\
\hline
\end{tabular}

Table 2 above explains the indicators that will be proposed to the respondents later. For the independent variable or variable $\mathrm{X}$, there are 4 questions. As for the dependent variable or variable $Y$ there are 5 questions. In determining indicators, the researcher refers to several previous studies. By measuring using a Likert scale of 1 to 5, where 1 means Strongly Disagree and 5 Strongly Agree.

\section{Data Analysis}

The respondents used were 175 respondents who met the research criteria. From all respondents who fill in the following is a table of results that summarizes the overall characteristics of the respondents:

Table (3): Respondent Data

\begin{tabular}{clcc}
\hline & Respondent Data & Number of Respondents & Percentage (\%) \\
\hline \multirow{2}{*}{ Gender } & Female & 87 & 49.71 \\
& Male & 88 & 50.29 \\
& $<17$ Years & 10 & 5.71 \\
& $18-28$ years & 43 & 24.57 \\
& $29-39$ years & 84 & 48 \\
& $>40$ Years & 38 & 21.72 \\
\hline \multirow{2}{*}{ Religion } & Islam & 175 & 100 \\
& Non-Islamic & 0 & - \\
\hline \multirow{2}{*}{ Origin } & Sumatra & 33 & 18.86 \\
& Java & 105 & 60 \\
& Kalimantan & 11 & 6.29 \\
\end{tabular}




\begin{tabular}{clcc}
\hline & Bali, NTT and NTB & 5 & 2.85 \\
& Maluku and Papua & 7 & 4 \\
\hline Profession & Housewife & 20 & 11.42 \\
& General employees & 65 & 37.15 \\
& Student / College Student & 17 & 9.71 \\
& Government Employees/ BUMN & 27 & 15.43 \\
& Entrepreneur / Trader & 46 & 26.29 \\
\hline \multirow{2}{*}{ Number of visits } & 1 time & 110 & 62.86 \\
& $2-4$ times & 54 & 30.86 \\
\multirow{5}{*}{ Reasons for visiting } & Work & 11 & 6.28 \\
& Holidays / Sightseeing & 60 & 34.29 \\
& Training / Seminar & 28 & 16 \\
& & 87 & 49.71 \\
\hline
\end{tabular}

Based on table 3 above, it can be concluded that in general the respondents who filled in were male, amounting to 88 respondents $(50.29 \%$ ) with the largest age range being 29 - 39 years as many as 84 respondents (48\%). Of the total respondents, 175 respondents are all Muslim. Based on the occupation of the most respondents are in private employee jobs with 65 respondents (37.15\%). The highest number of visits was 1 time with 110 respondents (62.86\%), the reason they visited the most was for training / seminars with 87 respondents (49.71\%) for the origin of the most respondents from Java Island $105(60 \%)$. Then here are the names of the hotels mentioned by the respondents:

Table (4): Name of Sharia Hotel

\begin{tabular}{|c|c|c|c|c|}
\hline No. & Hotel Name & Territory & Number of Respondents & $\%$ \\
\hline 1 & Aedo Hotel Syariah (Bukittinggi) & Sumatra & 5 & 2.86 \\
\hline 2 & Akbar Hotel Syariah (Purwokerto) & Java & 1 & 0.57 \\
\hline 3 & Al Badar Hotel Syariah (Makassar) & Sulawesi & 5 & 2.86 \\
\hline 4 & Al Faith Syariah (Tegal) & Java & 1 & 0.57 \\
\hline 5 & Al Thalib Hotel Syariah (Jakarta) & Java & 5 & 2.86 \\
\hline 6 & Alyah Guest House Syariah (Ambon) & Maluku and Papua & 2 & 1.14 \\
\hline 7 & Arrayan Malioboro Syariah & Java & 1 & 0.57 \\
\hline 8 & Bayt Kaboki Hotel (Bali) & Bali, NTT, NTB & 2 & 1.14 \\
\hline 9 & Bluebells Express Hotel Syariah (Malang) & Java & 2 & 1.14 \\
\hline 10 & Cinnamon Hotel Boutique Syariah (Bandung) & Java & 3 & 1.71 \\
\hline 11 & Daarul Jannah Hotel (Bandung) & Java & 1 & 0.57 \\
\hline 12 & D'Gria Hotel Syariah (Serang) & Java & 2 & 1.14 \\
\hline 13 & DWD Hotel Syariah (Banjarmasin) & Borneo & 2 & 1.14 \\
\hline 14 & Ermahadi Homestay Syariah (Blitar) & Java & 1 & 0.57 \\
\hline 15 & Grand Bunda Hotel Syariah (Bukittinggi) & Sumatra & 4 & 2.29 \\
\hline 16 & Grand Dafam Rohan (Yogjakarta) & Java & 1 & 0.57 \\
\hline 17 & Grand Kalimas Hotel Syariah (Surabaya) & Java & 4 & 2.29 \\
\hline 18 & Grand Madani Syariah (Mataram) & Bali, NTT, NTB & 1 & 0.57 \\
\hline 19 & Hannah Hotel Syariah (Painan) & Sumatra & 1 & 0.57 \\
\hline 20 & Home Anaya Hotel Syariah (Medan) & Sumatra & 2 & 1.14 \\
\hline 21 & Hotel Adilla Syariah (Yogjakarta) & Java & 5 & 2.86 \\
\hline 22 & Hotel AIA Putih Syariah (Payakumbuh) & Sumatra & 1 & 0.57 \\
\hline 23 & Hotel Al Zara Syariah (Yogjakarta) & Java & 2 & 1.14 \\
\hline 24 & Grand Darussalam Syariah Hotel (Medan) & Sumatra & 5 & 2.86 \\
\hline 25 & Hotel Green Alia Cikini (Jakarta) & Java & 1 & 0.57 \\
\hline 26 & Hotel Griya Duta (Banjarmasin) & Borneo & 1 & 0.57 \\
\hline 27 & Hotel House of Eva (Jakarta) & Java & 5 & 2.86 \\
\hline 28 & Hotel Ibrahim Syariah Simpang Lima (Semarang) & Java & 4 & 2.29 \\
\hline 29 & Aceh House Islamic Hotel & Sumatra & 1 & 0.57 \\
\hline 30 & Hotel Kyriad Pesonna Gresik & Java & 2 & 1.14 \\
\hline 31 & Hotel Madani (Medan) & Sumatra & 8 & 4.57 \\
\hline 32 & Hotel Mira Syariah (Cirebon) & Java & 2 & 1.14 \\
\hline 33 & Hotel Narapati Indah Syariah (Bandung) & Java & 2 & 1.14 \\
\hline 34 & Hotel Nusantara Indah (Jakarta) & Java & 1 & 0.57 \\
\hline 35 & Hotel Nusantara Syariah (Lampung) & Sumatra & 3 & 1.71 \\
\hline 36 & Hotel Prima Graha Syariah (Kudus) & Java & 1 & 0.57 \\
\hline 37 & Hotel Putra Mulia Syariah (Bekasi) & Java & 1 & 0.57 \\
\hline 38 & Riez Palace (Tegal) Hotels & Java & 2 & 1.14 \\
\hline 39 & Hotel Sofyan Inn Unisi (Yogjakarta) & Java & 1 & 0.57 \\
\hline 40 & Hotel Syariah Atiqah (Pinrang) & Sulawesi & 3 & 1.71 \\
\hline 41 & Hotel Syariah Walisongo (Surabaya) & Java & 7 & 4 \\
\hline 42 & Zahra Hotels (Kendari) & Sulawesi & 2 & 1.14 \\
\hline 43 & Lingga Hotel (Bandung) & Java & 3 & 1.71 \\
\hline 44 & Jakarta Jaya Hotel Syariah & Java & 1 & 0.57 \\
\hline 45 & Mangkuto Hotel Syariah (Payakumbuh) & Sumatra & 1 & 0.57 \\
\hline 46 & N1 Hotel Syariah (Ternate) & Maluku and Papua & 1 & 0.57 \\
\hline 47 & Novon Family Hotel (Malang) & Java & 1 & 0.57 \\
\hline 48 & Namira Syariah Hotel (Surabaya) & Java & 2 & 1.14 \\
\hline 49 & Permata Hati Hotel and Convention Center (Aceh) & Sumatra & 2 & 1.14 \\
\hline 50 & OYO 343 Lawang 15 Syariah (Palembang) & Sumatra & 2 & 1.14 \\
\hline 51 & Orange Homes Syariah (Bandung) & Java & 2 & 1.14 \\
\hline 52 & Primaesa Residence (Manado) & Sulawesi & 2 & 1.14 \\
\hline 53 & Q Grand Dafam Syariah (Banjarbaru) & Borneo & 4 & 2.29 \\
\hline 54 & Pesonna Hotel (Semarang) & Java & 1 & 0.57 \\
\hline 55 & Red doorz Sharia & - & 2 & 1.14 \\
\hline 56 & Hotel Semesta (Semarang) & Java & 5 & 2.86 \\
\hline 57 & Ruby Hotel Syariah (Bandung) & Java & 2 & 1.14 \\
\hline
\end{tabular}




\begin{tabular}{|c|c|c|c|c|}
\hline 58 & Royal Homy Syariah (Yogjakarta) & Java & 1 & 0.57 \\
\hline 59 & Seroja Hotel Syariah (Balikpapan) & Borneo & 3 & 1.71 \\
\hline 60 & Sofyan Hotel Cut Meutia Cikini & Java & 4 & 2.29 \\
\hline 61 & Sofyan Hotel Soepomo Tebet & Java & 3 & 1.71 \\
\hline 62 & Syariah Hotel Solo & Java & 5 & 2.86 \\
\hline 63 & Syariah Lombok Hotel & Bali, NTT, NTB & 2 & 1.14 \\
\hline 64 & Sulaiman Residence Syariah (Padang) & Sumatra & 1 & 0.57 \\
\hline 65 & The Amrani Syariah Hotel (Solo) & Java & 2 & 1.14 \\
\hline 66 & Sharia Radho Hotel (Malang) & Java & 3 & 1.71 \\
\hline 67 & The Garden Syariah Hotel (Bogor) & Java & 1 & 0.57 \\
\hline 68 & ZEN Rooms Syariah & - & 5 & 2.86 \\
\hline 69 & UQ Hotel Syariah (Palu) & Sulawesi & 2 & 1.14 \\
\hline 70 & Wisma Pakuan Syariah Hotel (Bogor) & Java & 2 & 1.14 \\
\hline 71 & The Wahidah Syariah Hotel (Banyuwangi) & Java & 2 & 1.14 \\
\hline \multirow[t]{2}{*}{72} & The Grand Santhi Hotel (Denpasar) & Bali, NTT, NTB & 2 & 1.14 \\
\hline & Total & & 175 & 100 \\
\hline
\end{tabular}

From table 4 above shows that Hotel Madani is a hotel that is often mentioned by respondents as many as 8 or the equivalent of 4.57\%. Followed by Hotel Syariah Walisongo Surabaya with 7 respondents or 4\%, then there are Aedo Hotel Syariah, Al Badar Hotel Syariah, Al Thalib Hotel Syariah, Hotel Adilla Syariah, Hotel Grand Darussalam Syariah, Semesta Hotel Semarang, Hotel House of Eva, Syariah Hotel Solo and ZEN Rooms Syariah has the same number of respondents, namely $2.86 \%$ or 5 respondents. Grand Bunda Hotel Syariah, Grand Kalimas Hotel Syariah, Hotel Ibrahim Syariah Simpang Lima, Q Grand Dafam Syariah, and Sofyan Hotel Cut Meutia Cikini has a number of respondents, namely 4 respondents. For the names of Sharia hotels or inns that have 3 or $1.71 \%$ respondents, Cinnamon Hotel Boutique Syariah, Hotel Nusantara Syariah, Hotel Syariah Atiqah Pinrang, Lingga Hotel, Seroja Hotel Syariah, Sofyan Hotel Soepomo Tebet, and Syariah Radho Hotel. There are 24 hotels or inns that have the same number of respondents, namely 2 or the equivalent of $1.14 \%$, their names are, Alyah Guest House Syariah, Bayt Kaboki Hotel, Bluebells Express Hotel Syariah, D'Gria Hotel Syariah, DWD Hotel Syariah, Home Anaya Hotel Syariah, Hotel Al Zara Syariah, Hotel Kyriad Pesonna Gresik, Hotel Mira Syariah, Hotel Narapati Indah Syariah, Hotel Riez Palace, Hotel Zahra Kendari, Namira Syariah Hotel, Permata Hati Hotel and Convention Center, OYO 343 Lawang 15 Syariah, Orange Homes Syariah, Primaesa Residence, Red doorz Syariah, Ruby Hotel Syariah, Syariah Lombok Hotel, The Amrani Syariah Hotel, UQ Hotel Syariah, Wisma Pakuan Syariah Hotel, The Wahidah Syariah Hotel and finally The Grand Santhi Hotel.

And if seen of the 175 respondents who filled in the name of the hotel, the island of Java was in the first rank of 42 Sharia hotels / inns. Then followed by the island of Sumatra with 13 Sharia hotels / inns. Furthermore, there are the islands of Sulawesi with 5 names of Sharia hotels / inns. For the islands of Kalimantan and Bali, NTT \& NTB, 4 respondents mentioned 4 names of Sharia hotels / inns. Finally, there are Maluku and Papua, there are 2 respondents who mentioned the names of the Sharia hotels / inns in the area. 2 respondents only mentioned the name of the hotel in general without giving specific details.

The following is a table that shows the study variables descriptive analysis:

Table (5): Descriptive Analysis Results

\begin{tabular}{lccc}
\hline & N & Mean Per Indicator & Mean Per Variable \\
\hline PP11 & 175 & 4.69 & \\
PP12 & 175 & 4.41 & 4.50 \\
PP13 & 175 & 4.45 & \\
PP14 & 175 & 4.45 & 4.31 \\
PP21 & 175 & 4.35 & \\
PP22 & 175 & 4.25 & \\
PP23 & 175 & 4.51 & 4.25 \\
PP24 & 175 & 4.13 & \\
PP31 & 175 & 4.38 & 4.52 \\
PP32 & 175 & 4.33 & \\
PP33 & 175 & 4.33 & \\
PP34 & 175 & 3.95 & 4.24 \\
PP41 & 175 & 4.65 & \\
PP42 & 175 & 4.47 & \\
PP43 & 175 & 4.54 & \\
PP44 & 175 & 4.42 & \\
PP51 & 175 & 4.07 & \\
PP52 & 175 & 4.38 & \\
PP53 & 175 & 4.63 & \\
PP54 & 175 & 3.86 & \\
PP61 & 175 & 4.14 & \\
PP62 & 175 & 4.72 & \\
PP63 & 175 & 4.22 & \\
PP64 & 175 & 4.06 & \\
PP71 & 175 & 4.46 & \\
PP72 & 175 & 4.33 & \\
PP73 & 175 & 4.36 & \\
PP74 & 175 & 4.58 & \\
\hline
\end{tabular}

Source: Results of Data Processing with SPSS 21 
From table 5 above, it shows that the average value of the overall PP62 with a value of 4.72 is in the very good category. The content of the indicator is regarding the processing of food and beverage ingredients, guaranteed to be halal. This illustrates that the respondent checks very carefully about the processing of food and beverages served. When viewed from each of the indicators for PP1 which have the highest mean or average value is in PP11 with a value of 4.69 this is in the very good category. This means that respondents are very aware that a sharia hotel / inn only provides halal food and drinks. Overall, from this PP1, the average value is 4.50. This means that the respondent has a very good attachment to the indicators given.

Then for PP2, the highest average answer lies in PP23, namely 4.5. This means that the information a respondent is looking for about hotels / inns should be very easy to get. Overall, the average value of the 4 indicators is 4.31. This shows that on average the respondents are very good at understanding what is being informed by the sharia hotel / lodging. The highest average value for PP3 lies in PP31 at 4.37. Respondents know very well that the price is directly proportional to the facilities that will be obtained. Overall, the average value of the 4 indicators is 4.25. This indicates that the price will affect what you will get later and the respondents already know this very well.

The highest mean value for PP4 is PP41 at 4.65, this is in the very good category. With a friendly receptionist both at check in and check out, it will affect the choice of respondents in choosing sharia hotels / inns. The average value obtained is 4.52. This illustrates that the respondent knows very well that what the hotel / lodging sells is not only rooms but also services, which cannot be measured with certainty. The highest mean value for PP5 is at PP53 at 4.62. Respondents argue that a sharia hotel is seen as a clean hotel room. Overall, from the four indicators, the average value is 4.24 . This is classified as very good, because it means that the respondents pay attention to the environment and the physical form of the hotel / inn.

The highest average value for PP6 was PP62 at 4.72. Respondents are very concerned about how the process of food and drinks served must be according to the guidelines to maintain halalness. Overall, the average value of the four indicators is 4.29. This illustrates those respondents are very concerned about how the process is applied by the hotel / inn. The highest average value for PP7 lies in PP74, namely 4.58. Respondents thought that the hotel / lodging they chose had to be close to the destination of the lodgers. The average value of all indicators is 4.43. This illustrates that the respondent will behave very well if the location of the hotel / inn can reach all, such as public transportation, the location they want to visit, friendly to Muslims and strategic.

After descriptive analysis, then hypothesis testing is carried out. From the coefficient determination test $\mathrm{R}^{2}$ results in an Adjusted R Square of 0.341 or $34.1 \%$. This illustrates that $34.1 \%$ of decisions to stay are influenced by the independent variables used in this study. Meanwhile, $65.9 \%$ explained by other variables outside the research model. When viewed from the whole using the $\mathrm{F}$ test. The data results show $\mathrm{F}_{\text {count }}$ value of 13,839 . From the quick look method, it can be seen that $F_{\text {count }}>4$, it can be stated that Ho is rejected. And if it is seen from the ANOVA table with 7 independent numbers and 175 samples used, it can be obtained that the $F_{\text {table }}$ value is 2.06 . It can be stated

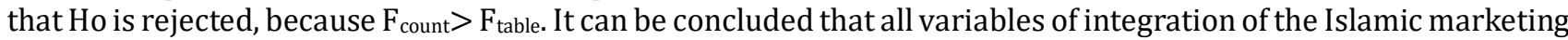
mix have a simultaneous influence on the decision to stay at a hotel / lodging in sharia. Furthermore, to prove the initial hypothesis, a t test was carried out to see whether there was any influence from each of the independent variables on the dependent variable. The following are the results of data processing:

Table (6): $t$ test results

\begin{tabular}{lccccc}
\hline \multicolumn{1}{c}{ Variable } & $\mathrm{t}_{\text {test }}$ & $\mathrm{t}_{\text {table }}$ & sig. & $\boldsymbol{\alpha}$ & Hypothesis Results \\
\hline PP1 & 1,935 & 1.97 & 0.055 & 0.05 & The initial hypothesis was rejected \\
PP2 & 1,485 & 1.97 & 0.140 & 0.05 & The initial hypothesis was rejected \\
PP3 & 1,475 & 1.97 & 0.142 & 0.05 & The initial hypothesis is accepted \\
PP4 & 0.219 & 1.97 & 0827 & 0.05 & The initial hypothesis is accepted \\
PP5 & 3,484 & 1.97 & 0.001 & 0.05 & The initial hypothesis was rejected \\
PP6 & 2,969 & 1.97 & 0.003 & 0.05 & The initial hypothesis is accepted \\
PP7 & 2,403 & 1.97 & 0.017 & 0.05 & The initial hypothesis is accepted \\
\hline
\end{tabular}

Source: Results of Data Processing with SPSS 21

Table 6 shows that there is There are 4 variables that do not affect the decision to stay at a sharia hotel / lodging, namely pragmatism and product, pertinence and promotion, palliation, and price \& peer-support and people. This can be seen from the smaller ttest than ttable or sig. value greater than the $\alpha$ value. Meanwhile, the variables that influence the decision to stay at a sharia hotel / lodging are pedagogy and physical environment, persistence and process \& patience and place. This can be seen from the value of the ttest is greater than the ttable or sig. value smaller than the $\alpha$ value.

\section{Discussion}

The results of this study indicate pragmatism and the product does not influence the decision to stay at a hotel / lodging in sharia. This means that hotel guests decide to stay overnight because of other factors. For questions regarding hotels only providing halal food and drinks, services must meet sharia service standards, get inner peace 
and there are no actions that are against Islamic law. Respondents assumed that the questions asked were not that important because it was an obligation for sharia hotels / inns to implement all of these. Therefore, the management of sharia hotels / inns can continue to maintain the standards of sharia hotels, or it can also be seen from the indicators in this study, namely maintaining halal food and drinks.

The test results show that there is no effect of pertinence and promotion of decisions to stay at sharia hotels / inns. Perhaps the cause of the different results from previous research is thought to be due to differences in the object and number of research samples. The respondents can assume that information on facilities, attractive and transparent promotions, the ease of getting information both in the hotel reservation application and the hotel / lodging website cannot influence respondents to stay at Islamic hotels / inns. It is possible that in informing the management services of sharia hotels / inns it is still not comprehensive, especially nowadays, which use technology to book hotels. Then it would be great if the information was clearly and transparently presented in the hotel booking application.

From the test results, it shows that the palliation and price do not influence the decision to stay at a sharia hotel / lodging. Respondents no longer consider prices when they want to stay. It is possible that the respondents assumed that transparency in setting prices would certainly match the facilities that would be obtained. So, the management has set prices according to the facilities. And in terms of service, it is also equivalent to the price you get. Then the promos offered are very attractive for customers to stay.

In this study shows that there is no relationship between peer-support and people with the decision to stay overnight. This suggests that the respondents may not perceive the receptionist as friendly at times check in nor check out as well as responding to complaints, security is always friendly and office boy not disturbing the comfort is something that should be done by sharia hotels / inns. Because they are selling a service that doesn't look real they should pay attention to this. Hotel / inn management has certainly implemented and paid attention to attitudes, behaviors and actions to maintain the comfort and safety of guests.

From the results of research, pedagogy and physical environment influence the decision to stay at Islamic hotels / inns. This means it is assumed that the respondents before their stay would pay attention to the availability of places of worship facilities, the size of the hotel / lodging building, cleanliness in hotel rooms and worship equipment. It is recommended that the management of sharia hotels / inns continue to improve 2 things, namely, firstly in terms of physical forms such as improving worship facilities (there are mosques / prayer rooms, prayer tools, and facilities on websites and Islamic hotel / lodging booking applications). Second, in the intangible form, namely in terms of building relationships between guests and visitors, this is useful for the long term for the company.

The test results show that persistence and process there is an influence on the decision to stay overnight. It is possible that the respondents pay attention to all processes starting from facilities in hotel reservations, processing food and beverage ingredients, and marketing must be in accordance with what is so that it can avoid misunderstandings from each party. It would be better if the management of Islamic hotels / inns is very transparent in terms of food and beverage processing, as well as the hotel reservation process both on the website and application to be made easier and in terms of marketing halal hotels / inns, it must be clear. By doing the above things can minimize misunderstandings from guests and make guests feel at home.

The result of the test states patience and place influences the decision to stay at a Sharia hotel / lodging. It is assumed that the respondents in choosing their Sharia hotel / lodging will look at their location, such as whether it is close to the city center, close to public transportation, a location that is friendly to Muslims and if you want to go somewhere, the place of the hotel / lodging must be close to it. So, the management of Islamic hotels / inns can pay attention to the location of Islamic hotels / inns, because hotel guests want to visit the places they want to go to (training outside the city or work outside the city) and close to the city center (for visitors who are on vacation or sightseeing) and the place should be close to public transport so they can stay overnight.

\section{Conclusion}

The results showed that simultaneously the integration of the Islamic marketing mix influences the decision to stay at a hotel / lodging in sharia. Whereas partially or individually the variables of pragmatism and product, pertinence and promotion, palliation, and price \& peer-support and people have no influence on decisions to stay at sharia hotels / inns and for pedagogy and physical environment, persistence and process \& patience and place influence decisions to stay at sharia hotels / inns.

\section{References}

- Al-Qur'an dan Hadits

1. Christiyanto, Wenda Wahyu \& Astutik, Mardi. (2018). Integrated Marketing and Customers' Decision Saving Funds in Islamic Banks. Journal of Economic and Business, 3(3): 377 - 398, https://doi.org/10.22515/shirkah.v3i3.216.

2. Firmansyah, M. Anang. (2018). Perilaku Konsumen (Sikap dan Pemasaran). Yogyakarta: Deepublish. 
3. Hashim, Nurhazirah \& Hamzah, Muhammad Iskandar. (2014). 7P's: A Literature Reviewof Islamic Marketing and Contemporary Marketing Mix. Pocedia - Social and Behavioral Sciences, 130: 155 - 159 , https://doi.org/10.1016/j.sbspro.2014.04.019.

4. Hermawan, Haris. (2015). Analisis Pengaruh Bauran Pemasaran Terhadap Keputusan, Kepuasan dan Loyalitas Konsumen Dalam Pembelian Roti Ceria di Jember. Journal Manajemen dan Bisnis Indonesia, 1(2).

5. Husen, Tamitha Intassar. \& Zhafira, Nabila Hilmy. (2019). Positionong Pariwisata Syariah Studi Kasus Pada Hotel Sofyan Syariah. Jurnal Bisnis dan Kajian Strategi Manajemen, 3 (1), https://doi.org/10.35308/jbkan.v3i1.1372.

6. James F. Engel, Roger D. Blackwell \& Paul W. Miniard. (1994). Perilaku Konsumen. Jakarta: Binarupa Aksara.

7. Kavanillah, Desy., \& Ridlwan, Ahmad Ajib. (2018). Pengaruh Bauran Pemasaran Jasa terhadap Keputusan Meningap di Hotel Andita Syariah Surabaya. Iqtishoduna, 7 (2): 146 - 164.

8. Kompas. (2020). BI: Industri Pariwisata Jadi Sektor Paling Hasilkan Devisa. Terbit 1 Juni 2020, http://kompas.com.

9. Kotler, Philip \& Amstrong. (1997). Dasar-Dasar Pemasaran. Jilid I, Jakarta: Prenballindo.

10. Mansyuroh, Firqah Annajiyah. (2018). Peluang dan Tantangan Bisnis Hotel Syariah Pada Masyarakat Kosmopolitan. Jurnal Studi Ekonomi, 9(2): 91 - 103.

11. Mardoni, Yosi. (2017). Etika Bisnis dalam Perspektif Islam. Jurnal Kewirausahaan Dalam Multi Perspektif.

12. Mujid, Abdul. (2016). Analisis terhadap Kosnep Syariah pada Industri Perhotelan di Indonesia. Jurnal Ilmu Syari'ah dan Hukum 50(2): 425 - 447.

13. Satriana, Eka Dewi dan Faridah, Hayyun Durrotul. (2018). Wisata halal: Perkembangan, Peluang, dan Tantangan. Journal of Halal Product and Research, 1(2): $32-43$.

14. Schiffman, Leon G., Kanuk \& Leslie Lazar. (2008). Perilaku Konsumen. Edisi Ketujuh. Alih Bahasa: Zoelkifli Kasip. Jakarta Indeks.

15. Sofyan, Riyanto. (2011). Bisnis Syariah Mengapa Tidak? Jakarta: Gramedia Pustaka Utama.

16. Sumantri, Rinol \& Yuliza, Nur Aisyah. (2015). Teori-Teori Etika Perilaku Bisnis dan Pandangan Islam Tentang Perilaku Etika Bisnis. Economic Journal, 1(1).

17. Syukur, Musthafa. (2018). Distribusi Perspektif Etika Ekonomi Islam. Jurnal Kajian Ekonomi dan Perbankan, 2 (2): 33 - 51.

18. Tehuayo, Erlinda. (2018). Analisis Proses Pengambilan Keputusan Konsumen Pada Perilaku Pembelian Produk Yamaha Mio di Kota Ambon. Journal SOSO2, 6 (2): 25 -34.

19. Widyawati, Lili. (2015). Pengaruh Pelayanan dan Harga Terhadap Keputusan Pembelian Smartphone Merek Samsung Pada UD. Surya Phone di Samarinda. eJournal Ilmu Administrasi Bisnis, 3(3): 574 - 586.

20. Wilson, Jonathan. (2012). Looking at Islamic marketing, branding and Muslim consumer behaviour beyond the 7P's. Journal of Islamic Marketing, 3(3): 212 - 216, https://doi.org/10.1108/17590831211259718. 